\title{
Relapsing insulin-induced lipoatrophy, cured by prolonged low-dose oral prednisone: a case report
}

Ernst A Chantelau ${ }^{1 *}$, Ruth Praetor ${ }^{2}$, Jörg Praetor ${ }^{2}$ and Ludger W Poll ${ }^{3}$

\begin{abstract}
Introduction: Circumscript, progressing lipoatrophy at the insulin injection sites is an unexplained, however rare condition in diabetes mellitus.

Case presentation: We report a case of severe localised lipoatrophy developing during insulin pump-treatment (continuous subcutaneous insulin infusion) with the insulin analogue lispro (Humalog ${ }^{\circledR}$ ) in a woman with type-1 diabetes mellitus. After 11 months of progressing lipoatrophy at two spots on the abdomen, low-dose prednisone (5-10 mg) p.o. was given at breakfast for 8 months, whereby the atrophic lesions centripetally re-filled with subcutaneous fat tissue (confirmed by MRI) despite ongoing use of insulin lispro. However, 4 weeks after cessation of prednisone, lipoatrophy relapsed, but resolved after another 2 months of low-dose prednisone. No further relapse was noted during 12 months of follow-up on insulin-pump therapy with Humalog ${ }^{\circledR}$.

Conclusion: Consistent with an assumed inflammatory nature of the condition, low-dose oral prednisone appeared to have cured the lipoatrophic reaction in our patient. Our observation suggests a temporary intolerance of the subcutaneous fat tissue to insulin lispro $\left(\mathrm{Humalog}^{\circledR}\right)$, triggered by an unknown endogenous mechanism.
\end{abstract}

\section{Background}

So-called insulin-induced lipoatrophy is a rare, albeit feared condition mostly in patients with type- 1 diabetes mellitus. It leads to a total loss of subcutaneous fat tissue at the sites of insulin injections. Neither the pathogenesis of the condition is known, nor the apparent female preponderance [1-14]. The clinical appearance is notable for its lack of inflammatory features. Histopathological reports were inconsistent: while subcutaneous fat atrophy and fibrosis was common, immunological abnormalities were found only in one of the studies (see Table 1). Insulin-induced lipoatrophy has been reported with the use of various pharmaceutical preparations, long acting or short acting insulin preparations, insulin analogues or human insulin, and with subcutaneous injection or continuous subcutaneous infusion (via insulin pump) treatment alike. Injection site lipoatrophy was also observed with the use of the somatostatin-analogue octreotide [8].

\footnotetext{
* Correspondence: chantelau@gmx.de

${ }^{1}$ Practice of Endocrinology and Diabetology, PD Dr.Kimmerle, Aachener Str.196, 40223 Düsseldorf/Germany

Full list of author information is available at the end of the article
}

\section{Case presentation}

We present the case of a 53 year old caucasian woman ( $R$. P., born 1956), who was diagnosed with type-1 diabetes mellitus at the age of 13 years. Since 1984 she was treated by continuous subcutaneous insulin infusion with a portable insulin pump using human regular insulin, without any adverse effects. Since 2004, insulin lispro (Humalog ${ }^{\circledR}$, Eli Lilly Deutschland, Bad Homburg, Germany) was used for insulin pump treatment (currently used device: AccuCheck Spirit $^{\circledR}$, Roche, Burgdorf, Switzerland). There was no co-morbidity except for Hashimoto's thyreoiditis, requiring $100 \mu \mathrm{g}$ levothyroxine once daily for substitution. There was no evidence for diabetic retinopathy, nephropathy or neuropathy, respectively. HbA1c (normal range 4$6 \%$ of total haemoglobin) was around $8 \%$, body mass index was $23.8 \mathrm{~kg} / \mathrm{m}^{2}$. In November 2007 and February 2008, vaccinations against hepatitis $\mathrm{A}$ and $\mathrm{B}$ were carried out with a vaccine containing traces of thiomersal (Twinrix ${ }^{\circledR}$, GlaxoSmithKline, Dresden, Germany). Commencing in May 2008, a lipoatrophic defect developed at the catheter insertion site on the right side of the abdominal wall, and after changing to the opposite side, a second lesion developed there. The size of both lesions increased steadily. In March 2009 hollows of $6 \times 7 \mathrm{~cm}$ had developed in the 
Table 1 Histopathological findings in insulin-induced circumscript lipoatrophy, as reported in the literature

\begin{tabular}{llllll}
\hline Previous reports, author & Reeves [1] & Jermendy [5] & Lopez [10] & Chantelau [3] & present case \\
\hline $\begin{array}{l}\text { cases,n } \\
\text { Skin: }\end{array}$ & 5 & 1 & 4 & 1 & \\
immunofluorescence staining* & positive & negative & not analysed & negative & not analysed \\
$\begin{array}{l}\text { mononuclear cell infiltration } \\
\text { Subcutaneous tissue: }\end{array}$ & mild & none & not analysed & mild & not analysed \\
fat tissue atrophy & present & absent? & present & present & present \\
focal fibrosis & absent? & absent? & present & present & present \\
lipoblast-like adipocytes & absent & present & absent & absent & absent \\
capillary proliferation & absent & present & absent & absent & absent \\
immunofluorescence staining* & not analysed & not analysed & negative & negative & not analysed \\
lymphocyte infiltration & absent & not analysed & mild & mild & not analysed \\
eosinophils infiltration & absent & not analysed & present & absent & not analysed \\
mast cells infiltration & absent & not analysed & present & absent & not analysed \\
\hline
\end{tabular}

*for lgG, IgA, IgM, C1, C3, and fibrin, or amyloid, respectively

subcutaneous fat tissue (Figure 1). Routine blood chemistry was normal. Immunological serum markers (anti-insulin antibodies, as well as antibodies against mitochondria, c-ANCA, p-ANCA, and ANA IgG) were negative. AntiTPO antibodies, however, were elevated $(173 \mathrm{U} / \mathrm{ml}$ (nor$\mathrm{mal}<60 \mathrm{U} / \mathrm{ml}$ )). In April 2009, a biopsy was obtained from the margin of the lipoatrophic area at the right lateral abdominal wall (Figure 1, lower panel). Routine histopathologic examination showed atrophic fat tissue (lipoatrophy); unfortunately, more detailed histochemical investigations were not performed. Assuming a potential adverse effect of $\mathrm{Humalog}^{\circledR}$, the insulin preparation was changed-over to rapid-acting genetically engineered human insulin ${\left(\text { Actrapid }^{\circledR}\right.}^{\circledR}$, NovoNordisk, Mainz, Germany), without obvious benefit. In consideration of an undefined immunologic pathogenesis, low-dose immunosuppressive treatment with $10 \mathrm{mg}$ prednisone once daily was commenced on June 23, 2009 (with adaptations of the insulin dosage, as appropriate, to maintain HbA1c between 7 and 8\%). As an immediate effect, no new lipoatrophic hollows developed at the catheter insertion sites in use. In August 2009, the existing hollows started to re-fill, beginning at the margins (Figure 1, 2). In September 2009, the daily prednisone dosage was reduced to $5 \mathrm{mg}$, and further to $2.5 \mathrm{mg}$ in October 2009. In December 2009, the patient decided to switch back from human insulin

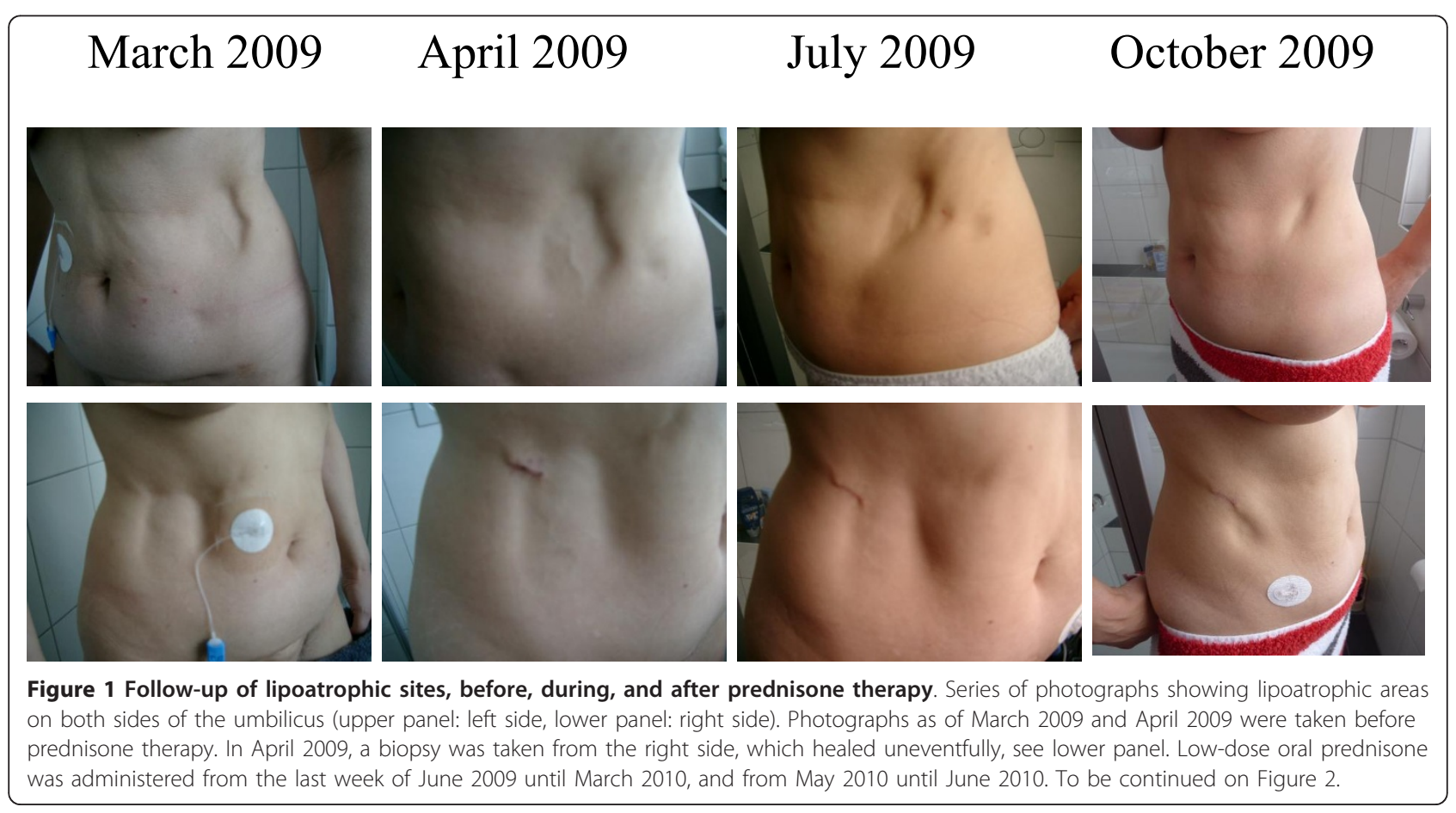




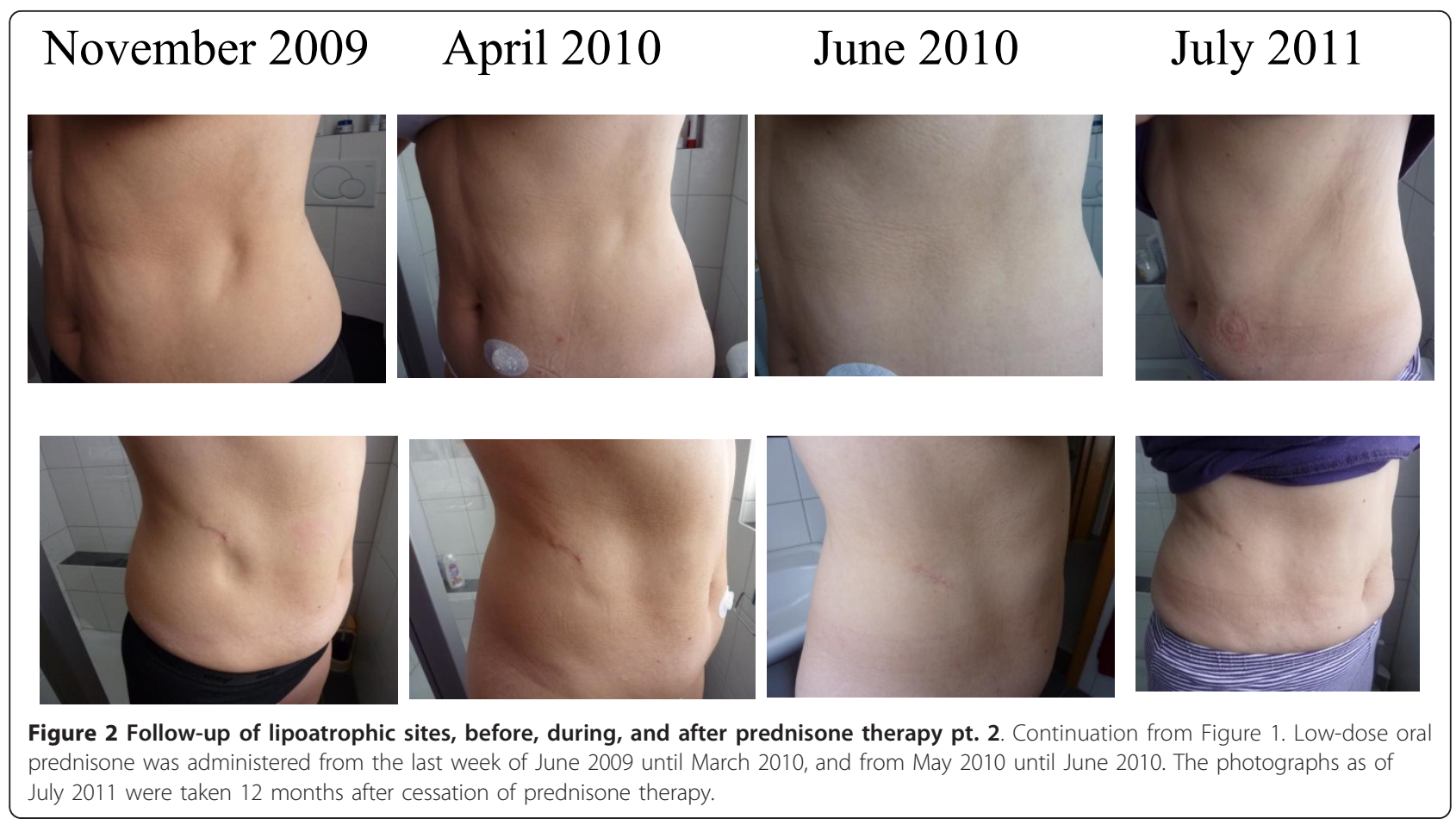

Actrapid $^{\mathbb{R}}$ ) to insulin lispro (Humalog ${ }^{\circledR}$ ), while the lipoatrophic hollows continued to re-fill with subcutaneous fat tissue rather than fibrous scar tissue (confirmed by MRI, see Figure 3). In March 2010, when the lipoatrophy was almost cured, prednisone was discontinued. The patient was advised to use the previously lipoatrophic areas again for catheter insertion. However, about 4 weeks later, prednisone had to be resumed because lipoatrophy had relapsed. By June 2010, after another 2 months of prednisone therapy, the lipoatrophic areas were cured again (Figure 2) and prednisone was tapered off. During the following 12 months on unchanged insulin-pump therapy using insulin lispro, no relapse of the lipoatrophy was noted (Figure 2).

However, 3 months after cessation of prednisone treatment, in both hands cheiroarthropathy developed with thickened flexor digitorum tendons and edema of the tendon sheaths, as evidenced by MRI [15]. Rheumatoid arthritis was ruled out on laboratory and imaging studies. The condition was markedly alleviated by physiotherapy.

\section{Discussion}

Our present observation in an adult patient is the first to show an acutely relapsing circumscript lipoatrophy at the sites of subcutaneous infusion of insulin lispro, which fully resolved by low-dose oral corticosteroid treatment. In a previous patient of ours, whose lipoatrophies seemingly stopped after changing from injections to insulin pump treatment [3], a relapse occurred after 5 years of insulin pump treatment and resolved during oral corticosteroid treatment (given to treat newly diagnosed arteriitis temporalis [E.A. Chantelau, unpublished observation]).

In contrast to adult patients, in whom insulin lipoatrophy rarely resolves spontaneously $[2,7,10,11,14]$, insulin lipoatrophy sometimes resolved spontaneously in children $[5,6,12,16]$. Hence, treatment of the condition is particularly warranted for adults. Changing the insulin brand, or changing from injections to continuous subcutaneous insulin infusion $[3,11]$ seemed to be equally ineffective. Empirical treatment based on topical corticosteroid injections (injection of dexamethasone into the lipoatrophic lesions) had resulted in return of subcutaneous fat tissue in an adult $[17,18]$ and in a child [9], but not in an infant [12]. Recently, topical disodium cromoglycate ointment was found effective in lipoatrophy of short duration by Lopez et al., who also reported that a long-standing chronic lipoatrophy was unresponsive to either topical disodium cromoglycate ointment or corticosteroid injections [10].

The present case report adds to the evidence, that a subclinical, subacute inflammatory reaction may be involved in the pathogenesis of insulin-induced lipoatrophy, since the destructive process may be suppressed and even reversed by administration of anti-inflammatory compounds (e.g. corticosteroids, disodium cromoglycate ointment). This process is different from the local inflammatory reaction that regularly occurs in the subcutaneous fat tissue after injection of insulin, insulin 


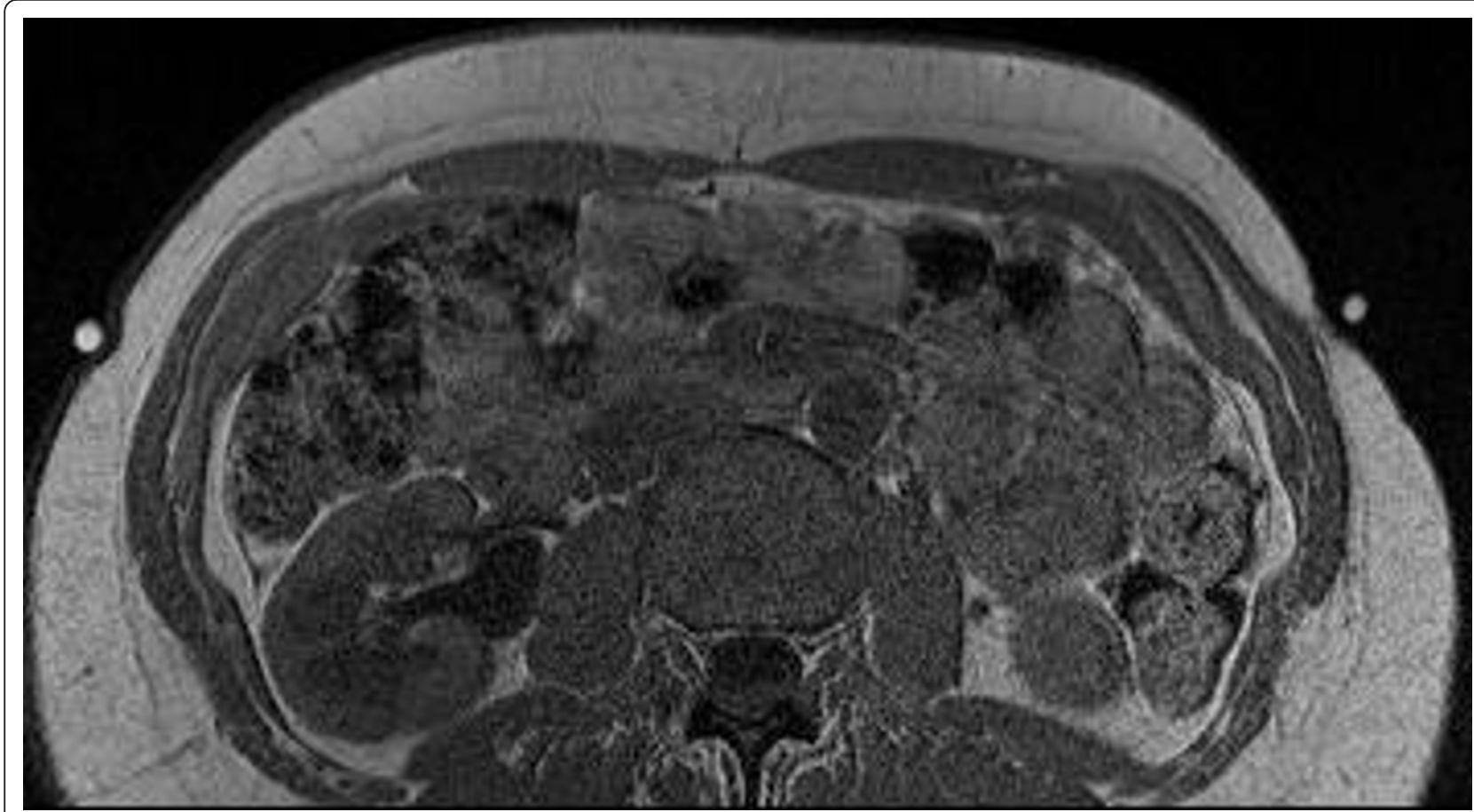

Figure 3 MRI demonstrating re-grown subcutaneous fat tissue at sites of previous lipoatrophy. Axial T1-weighted MRI sequence (1.5 Tesla Magnet, body surface coil, slice thickness $3 \mathrm{~mm}$ ) acquired through the abdomen, March 2010. Markers are placed over the healed lipoatrophic area (left side), and over the biopsy scar (right side), respectively. Signal intensity and subcutaneous tissue structure indicate regrown subcutaneous fat tissue at the healed area (left side; high signal intensity, identical to that of periumbilical subcutaneous fat tissue), and fibrous tissue at the biopsy area, respectively (right side; signal intensity is only half of that of subcutaneous fat tissue).

analogues or other compounds $[1,10,19,20]$. However, the underlying mechanisms of injection-induced subcutaneous lipoatrophy remain to be determined. A personal susceptibility might be involved, as has been suggested by Atmaca et al. [8], which might be transitory, as our case seems to indicate. The trigger of such a transitory intolerance remains unknown, as well as the female preponderance of the condition.

\section{Conclusion}

In conclusion, the case of our patient supports the use of prolonged low-dose corticosteroid treatment to cure progressive insulin-induced lipoatrophy. A careful adaptation of the insulin dose is mandatory in order to avoid corticosteroid-induced hyperglycaemia.

\section{Consent}

Written informed consent was obtained from the patient for publication of this case report and accompanying images. A copy of the written consent is available for review by the Editor-in-Chief of this journal.

\section{Author details}

${ }^{1}$ Practice of Endocrinology and Diabetology, PD Dr.Kimmerle, Aachener Str.196, 40223 Düsseldorf/Germany. ${ }^{2}$ Cäcilienstr.40, 48431 Rheine/Germany.
${ }^{3}$ Department of Radiology, Berufsgenossenschaftliche Unfallklinik Duisburg GmbH, Großenbaumer Allee 250, 47249 Duisburg/Germany.

\section{Authors' contributions}

EC conceived the idea, compiled the data and drafted the paper. RP and JP contributed patient data and the photographs. LWP provided the MR imaging analysis and participated in writing the paper. All authors read and approved the final manuscript.

\section{Competing interests}

The authors declare that they have no competing interests.

Received: 5 August 2011 Accepted: 6 December 2011 Published: 6 December 2011

\section{References}

1. Reeves WG, Allen BR, Tattersall RB: Insulin-induced lipoatrophy: evidence for an immune pathogenesis. Br Med J 1980, 280:1500-1503.

2. Rosman MS: Fat atrophy in human insulin therapy. (Letter). Diabetes Care 1986, 9:436.

3. Chantelau E, Reuter M, Schotes S, Starke AAR: A Case of lipoatrophy with human insulin-therapy. Exp Clin Endocrinol Diabetes 1993, 101:194-196.

4. Logwin S, Conget I, Jansa M, Vidal M, Nicolau C, Gomis R: Human insulininduced lipoatrophy. Diabetes Care 1996, 19:255-256.

5. Jermendy G, Nadas J, Sapi Z: 'Lipoblastoma-like' lipoatrophy induced by human insulin-morphological evidence for local dedifferentiation of adipocytes? (Letter). Diabetologia 2000, 43:955-956.

6. Griffin ME, Feder A, Tamborlane WV: Lipoatrophy associated with lispro insulin in insulin pump therapy. (Letter). Diabetes Care 2001, 24:174.

7. Ampudia-Blasco FJ, Girbes J, Carmena R: A case of lipoatrophy with insulin glargine. (Letter). Diabetes Care 2005, 28:2983. 
8. Atmaca A, Erbas T: Lipoatrophy induced by subcutaneous administration of octreotide in the treatment of acromegaly. Exp Clin Endocrinol Diabetes 2005, 113:340-343.

9. Ramos AJS, Farias MA: Human insulin-induced lipoatrophy. Successful treatment with glucocorticoid. Diabetes Care 2006, 29:926-927.

10. Lopez X, Castells MC, Ricker A, Velazquez EF, Mun E, Goldfine AB: Human insulin analog-induced lipoatrophy. Diabetes Care 2008, 31:442-444.

11. Arranz A, Andia V, Lopez-Guzman A: A case of lipoatrophy with lispro insulin without insulin pump therapy. (Letter). Diabetes Care 2004, 27:625-626.

12. Noud MN, Renard E, McBride C, Cotterill AM, Harris M: Benefits of intraperitoneal insulin administration in a child with severe insulin-induced lipoatrophy. (Abstract). Pediatric Diabetes 2009, 10(Suppl 11):100.

13. Sackey AH: Injection-site lipoatrophy. New Engl J Med 2009, 361:e41.

14. Holstein A, Stege H, Kovacs P: Lipoatrophy associated with the use of insulin analogues: a new case associated with the use of insulin glargine and review of the literature. Exp Opin Drug Saf 2009, 9:225-231.

15. Khanna G, Ferguson P: MRI of diabetic cheiroarthropathy. Am J Roentgen 2007, 188:W94-W95.

16. Babiker A, Datta V: Lipoatrophy with insulin analogues in type 1 diabetes. Arch Dis Child 2011, 96:101-102

17. Whitley TH, Lawrence PA, Smith CL: Amelioration of insulin lipoatrophy by dexamethasone injection. JAMA 1976, 235:839-840.

18. Kumar D, Miller LV, Mehtalia SD: Use of dexamethasone in treatment of insulin lipoatrophy. Diabetes 1977, 26:296-299.

19. Markussen J, Havelund S, Kurtzhals P, Andersen AS, Halstrom J, Hasselager E, Larsen UD, Ribel U, Schäffer L, Vad K, Jonassen I: Soluble, fatty acid acylated insulins bind to albumin and show protracted action in pigs. Diabetologia 1996, 39:281-288.

20. Oliver DJ, Sykes NP, Carter RL: Histopathological study of subcutaneous drug infusion sites in patients dying of cancer. (Letter). Lancet 1988, 331:478.

doi:10.1186/1758-5996-3-33

Cite this article as: Chantelau et al:: Relapsing insulin-induced lipoatrophy, cured by prolonged low-dose oral prednisone: a case report. Diabetology \& Metabolic Syndrome 2011 3:33.

\section{Submit your next manuscript to BioMed Central} and take full advantage of:

- Convenient online submission

- Thorough peer review

- No space constraints or color figure charges

- Immediate publication on acceptance

- Inclusion in PubMed, CAS, Scopus and Google Scholar

- Research which is freely available for redistribution

Submit your manuscript at www.biomedcentral.com/submit
Biomed Central 